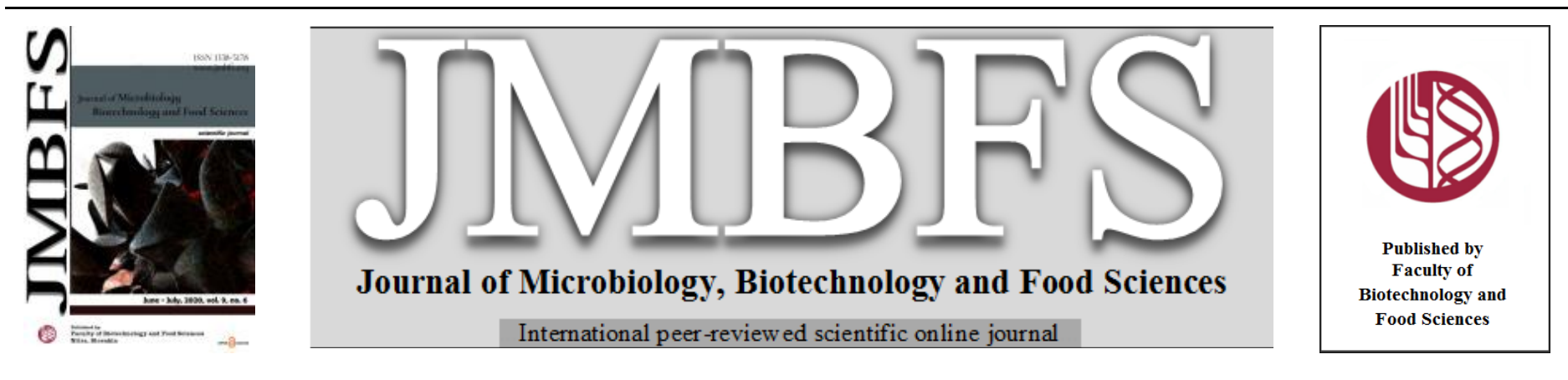

\title{
HEAT AND PH STABLE PROTEASE PRODUCED BY A BACTERIUM ISOLATED FROM FIELDS WITH HIGH BORON
}

\author{
Esma YİĞIT ŞAT ${ }^{l}$, Belma NURAL YAMAN², Serap GEDIKLİ̈, Pinar AYTAR ÇELIK ${ }^{2,4 *}$, Ahmet ÇABUK ${ }^{1,5}$ \\ Address(es): Dr. Pınar Aytar Çelik, \\ ${ }^{1}$ Graduate School of Natural and Applied Science, Department of Biotechnology and Biosafety, Eskisehir Osmangazi University, 26040, Eskisehir, Turkey. \\ ${ }^{2}$ The Faculty of Engineering and Architecture, The Department of Biomedical Engineering, Eskisehir Osmangazi University, 26040 Eskisehir, Turkey. \\ ${ }^{3}$ Graduate School of Natural and Applied Science, Department of Biology, Eskisehir Osmangazi University, 26480, Eskisehir, Turkey. \\ ${ }^{4}$ Mahmudiye Horse Breeding Vocational School, Eskisehir Osmangazi University, Eskisehir, Turkey. \\ ${ }^{5}$ Department of Biology, Faculty of Arts and Science, Eskisehir Osmangazi University, 26480, Eskisehir, Turkey.
}

*Corresponding author: pinaraytar@gmail.com

doi: 10.15414/jmbfs.2020.9.6.1047-1052

\section{ARTICLE INFO}

Received 9. 10. 2018

Revised 18. 12. 2019

Accepted 10. 1.2020

Published 1. 6. 2020

Regular article open $\bigodot_{\text {ACCESS }}$

\begin{abstract}
In this study, production, optimization and characterization of protease produced by a bacterium isolated from Kurka boron mine distinct were performed.

The proteolytic activities of isolates were screened based on Anson method. The optimal production conditions for protease were determined by using Central Composite Design.

Bacillus sp. DB14 isolate (accession number: KY110868) exhibited the highest activity in terms of protease enzyme (346.15 U/mg) among the other isolates screened. The highest result for protease activity of Bacillus sp. DB14 isolate was obtained as $481.76 \mathrm{U} / \mathrm{mg}$ according to experimental set. Optimum pH and temperature of Bacillus sp. DB14 protease were found as 10.5 and $60^{\circ} \mathrm{C}$, respectively. Interestingly, this enzyme could stand stable at the range of $20-50{ }^{\circ} \mathrm{C}$. However, the enzyme activity started to decrease highly after $50^{\circ} \mathrm{C}$. Besides, $\mathrm{pH}$ stability of this enzyme was provided between $\mathrm{pH} 7$ and $\mathrm{pH} 11$. Inhibition of protease was observed in solution with $10 \mathrm{mM} \mathrm{Ni}^{2+}, \mathrm{Fe}^{3+}, \mathrm{Hg}^{2+}, \mathrm{Cd}^{2+}$ and $\mathrm{B}^{3+}$. $\mathrm{Cu}^{2+}$ ion was found to enhance enzyme activity.

Bacillus sp. DB14 protease exhibited remarkably stability in the temperature range of $20{ }^{\circ} \mathrm{C}$ and $50{ }^{\circ} \mathrm{C}$. Proteolytic activity values obtained at the range of $\mathrm{pH} 7-11$ were stable. These results indicated that the alkaline protease from this isolate might be potential for biotechnological applications.
\end{abstract}

Keywords: Protease, boron-tolerant, characterization

\section{INTRODUCTION}

Boron has been proposed as a significant non-metal micronutrient in microorganisms, plants and animals (Warington, 1923; Rowe and Eckhert, 1999). Apart from cyanobacteria (Mateo et al., 1986), boron has been reported to be vital for several bacteria. Furthermore, boron containing molecules have involved in quorum sensing mechanism (Chen $\boldsymbol{e t}$ al., 2002) and cell signaling mechanisms (Gonzalez-Fontes et al., 2008). Also, antibiotics containing boron such as boromycin and tartrolon are known to produce through bacterial synthesis (Irschic et al., 1995; Kohno et al., 1996). Nevertheless, boron may be toxic in live organisms such as bacteria and plant (Korkmaz et al., 2018). In addition, it has been found that the key role of boron is the cross linking of cell wall constituents such as rhamnogalacturonan-II and pectin in plants (Kobayashi et al., 1996). Moreover, boron forms complexes with glycoproteins in membrane structures (Goldbach and Wimmer, 2007) and it has been postulated that is essential for stabilization of molecules with cis-diol groups (Bolanos, 2004).

Besides, recently, new bacterial strains from fields containing high boron concentration have been isolated. Ahmed and colleagues isolated the strains required boron for the growth and these strains tolerated more than $450 \mathrm{mM}$ boron (Ahmed et al., 2007). Ahmed and Fujiwara isolated some boron tolerant bacteria from soil samples and showed that these isolates belonged to the six genera such as Bacillus, Arthrobacter, Algoriphagus, Gracilibacillus, Lysinibacillus and Rhodococcus (Ahmed and Fujiwara, 2010).

Even, the significance of boron is intensely linked to its implications in the prebiotic origins of genetic material (Scorei, 2012). According to this argument, the ribose furanosyl borate ester remains possibly the most essential borate sugar in the building process of the "RNA world".

The microbes requiring or tolerating harsh conditions are known as extremophile or extremotolerant. Studies on these microorganisms are essential owing to determination of microbial diversity and their biotechnological applications (Satyanarayana et al., 2005; Aytar et al., 2013; Aytar et al., 2015).
Especially, extremophile enzymes called as extremozymes have been stated to be resistant to chaotropic agents, detergents, extreme $\mathrm{pH}$ and temperature conditions and organic solvents (Akkır et al., 2017). Among these enzymes, proteases are one of the most significant industrial enzymes utilized in various sectors (Berneman, 2001).

Proteases (EC 3.4.2124) which breaks the peptide bonds in amino acid residues of other enzymes are member of the class of hydrolases. They are utilized in the large industrial applications such as detergent, leather, pharmaceutical, protein processing, foods (Hakim et al., 2018; Lakshmi et al., 2018). The proteases are one of the vital enzymes which account $40 \%-60 \%$ of the total worldwide enzymes sales (Harer $\boldsymbol{e t}$ al., 2018; Hakim $\boldsymbol{e t}$ al., 2018). Microbial enzymes are more efficient compared to enzymes of other organisms such as plant and animal (Banerjee et al., 1999). Because microorganisms can grow rapidly in inexpensive culture medium and their enzymes have efficient catalytic activity, stability to extreme temperature or $\mathrm{pH}$ and high productivity (Hasan et al., 2006).

Indeed, boron may have a main role in controlling certain pathways using serine protease or oxidoreductase, which is an enzyme relating to pyridine and flavin nucleotides. These biocatalysts need to pyridine or flavin nucleotides and by forming transition state analogs or competing for NAD or FAD, boron reversibly inhibits their activities (Hunt, 1998; Hunt, 2012).

Although there are several studies on isolating boron-tolerant bacteria and determining bacterial diversity, there has been no study of biotechnological applications of these bacteria in the literature. The target of this study to determine optimum conditions of production of extracellular protease obtained from Bacillus sp. DB14 strain from Kırka boron mine distinct. 


\section{MATERIALS AND METHODS}

\section{Isolation of microorganisms}

The isolation procedure of these microorganisms was previously explained in ou paper (Nural Yaman et al., 2019). The soil and water samples from boron mine fields in Kırka, Eskișehir were collected. Soil $(10 \mathrm{~g})$ or water $(10 \mathrm{ml})$ sample were suspended in $0.9 \% \mathrm{NaCl}$ solutions $(90 \mathrm{ml})$ and a set of serial dilutions was performed. Soil or water dilutions were plated onto Luria Bertani (LB) agar ( $\mathrm{pH}$ 7.0) including 50 and $100 \mathrm{mM}$ boric acid and incubated at $30{ }^{\circ} \mathrm{C}$ for $72 \mathrm{~h}$ Purified isolates were stored at the refrigerator in glycerol stock at $-20{ }^{\circ} \mathrm{C}$.

\section{Protease production medium and screening of proteolytic activity}

All isolates were transferred to basal culture medium to produce protease, which involved $(\mathrm{g} / \mathrm{l})$ glucose, 10; peptone, 5; yeast extract, 5; calcium chloride 0.1 ; sodium chloride, 0.5 ; potassium dihydrogen phosphate, 0.4; dipotassium hydrogen phosphate, 0.3 and magnesium sulphate, 0.1 . After the $\mathrm{pH}$ was adjusted to $7.5,1 \%(\mathrm{v} / \mathrm{v})$ of seed culture was inoculated to the medium, and then incubated at $30{ }^{\circ} \mathrm{C}$ for $24 \mathrm{~h}$. The culture was centrifuged at $10000 \mathrm{rpm}$ for 5 minutes, and protease activity was determined in the supernatant.

The investigation of protease activity was performed by the Anson method (Takami et al., 1989). Protein concentrations were determined through the Bradford method (Bradford 1976). The amount of the enzyme resultant from the release of $1 \mathrm{mg}$ of tyrosine each minute at $30{ }^{\circ} \mathrm{C}$ is determined as one unit of enzyme activity (Özçelik et al., 2013; Akkır et al., 2017).

The strain exhibiting maximum proteolytic activity was chosen for other experiments.

\section{Experimental design}

Among the isolates, DB14 isolate showing higher protease activity was chosen for enzyme production. In this study, $\mathrm{pH}$, incubation time, inoculum amount and their interactions which are contemplated to be efficient parameters on the enzyme specific activity $(\mathrm{U} / \mathrm{mg})$ were defined with mathematical models utilizing Central Composite Design method via Trial version of Design Expert 10.0.6 software for statistical design in the production of protease under controlled temperature $\left(30^{\circ} \mathrm{C}\right)$. The $\alpha$ value in the calculation of axial points was taken as through the software for orthogonal quadratic design. Dependent parameters and their levels for this work are shown in Table 1. To define the impacts of three parameters shown in this table, 20 tests were performed with axial points. For the period of the model formation from the experiment results, the terms to be included in the model were chosen by using backwards elimination method due to the existence of quadratic terms. Besides, the interactions of these parameters were investigated.

\section{Enzyme characterization}

Determination of optimum temperature and $\mathrm{pH}$

To determine the optimum $\mathrm{pH}$ and temperature for proteolytic activity, casein was dissolved in $50 \mathrm{mM}$ of glycine- $\mathrm{NaOH}$ buffer at $\mathrm{pH}$ and temperature values ranging from 8.0 to 12.0 and from 20 to $80^{\circ} \mathrm{C}$, respectively.

\section{Determination of thermostability and pH stability}

The maximum activity of the raw protease was expressed as $100 \%$. Based on this phrase, the relative activity of the protease for all experiments was calculated. Thermal stability was examined by pre-incubating the culture supernatant at different temperatures: $20-60{ }^{\circ} \mathrm{C}$ for $1 \mathrm{~h}$ before measuring protease activity, which was measured as described above. The protease $\mathrm{pH}$ stability was defined for various $\mathrm{pH}$ values ranging from 7.0 to 12.5 for $1 \mathrm{~h}$ at $30^{\circ} \mathrm{C}$.

Impact of different metals, metalloid and denaturants on proteolytic activity

To investigate the impact of heavy metals and metalloid as well as $\mathrm{NiCl}_{2}, \mathrm{FeCl}_{3}$, $\mathrm{HgCl}_{2}, \mathrm{CdCl}_{2}, \mathrm{H}_{3} \mathrm{BO}_{3}$ and $\mathrm{CuSO}_{4}$, the proteolytic enzyme was incubated for 20 min separately with each of these metals at a final concentration of $10 \mathrm{mM}$

The protease was incubated with SDS and EDTA at a final concentration of 0.5 and $1.0 \mathrm{mM}$. Furthermore, the same enzyme was incubated with urea at a final concentration of $0.5-1.0-5.0-10.0-100.0 \mathrm{mM}$ to define the enzyme stability.
Control solution prepared without any denaturant was utilized in each of the tests and investigated for comparison.

The relative activity was calculated utilized crude protease. Control solution prepared without any metal and metalloid ions was applied in the tests and investigated for comparison.

\begin{tabular}{lc} 
Table 1 The results of screening experiments & \\
\hline Isolate & Specific activity (U/mg) \\
\hline B1 & 53.82 \\
B2 & 151.12 \\
B3 & 118.37 \\
B4 & 142.93 \\
B5 & 92.55 \\
B6 & 104.60 \\
B7 & 136.68 \\
B8 & 133.58 \\
B10 & 96.20 \\
B11 & 94.49 \\
B12 & 115.49 \\
B13 & 126.77 \\
B14 & 79.01 \\
B15 & 133.49 \\
B16 & 118.58 \\
B17 & 137.81 \\
DB1 & 134.27 \\
DB3 & 267.84 \\
DB4 & 118.51 \\
DB14 & 346.15 \\
DB23 & 242.61 \\
DB24 & 120.09 \\
\hline
\end{tabular}

\section{RESULTS AND DISCUSSION}

\section{Screening of isolates for protease production}

In our previous study, nine of the isolates were isolated on LB agar with $100 \mathrm{mM}$ boric acid and the others were isolated on LB agar with $50 \mathrm{mM}$ boric acid (Nural Yaman et al., 2019). After all isolates were transferred to basal medium to produce proteolytic activity, the specific activities of 23 isolates obtained from the Kırka boron mine distinct in Eskişehir Province were determined by measuring the amount of total protein and protease activity. Bacillus sp. DB14 isolate (accession number: KY110868) exhibited the highest activity in terms of protease enzyme $(346.15 \mathrm{U} / \mathrm{mg})$ among the other isolates, and this isolate was therefore chosen for further studies. The specific activity values of all of the tested strains are given in Table 1.

\section{Effects of parameters on specific protease activity}

The production of proteolytic enzyme by Bacillus sp. DB14 isolate was indicated in Table 2. Variance analyses of three response variables were carried out and the regression models were represented utilizing Design Expert program. The graphs were utilized to define the main effects of parameters such as their interactions on the response variables. As shown in Table 2, the highest result for protease activity was reached to $481.76 \mathrm{U} / \mathrm{mg}$. The reduced result of variance analysis (ANOVA) of specific activity was indicated in Table 3 . This model was found to be statistically significant because their p-values $(<0.0001)$ (for all response variables) are less than 0.05 . Predicted specific activity value represents approximately $90 \%$ of actual activity. Experimental error was not obtained to be statistically significant because the p-value of lack of fit (0.67) was more than 0.05 for enzyme specific activity value.

Regression coefficient value calculated based on the coded values of the terms of the model formed after statistical analysis was shown in the same table. By means of these variance analyses, the regression model was given in Eq. (1).

Specific activity $\left(\frac{U}{m g}\right)=345.58-33.56 * A+18.30 * B-3.29 * C-$ $10.52 * A * B+21.13 * A * C+32.06 * B^{2}+14.38 * C^{2}$

\section{Equation 1}


Table 2 Design matrix and results of experiments

\begin{tabular}{lcccc}
\hline \multicolumn{5}{c}{ Parameters } \\
\hline Standard order & A:pH & $\begin{array}{c}\text { B:Incubation time } \\
\text { (day) }\end{array}$ & $\begin{array}{c}\text { C:Inoculum amount } \\
(\boldsymbol{\%})\end{array}$ & $\begin{array}{c}\text { Response: Specific activity } \\
\text { (U/mg) }\end{array}$ \\
\hline 1 & 6.5 & 1 & 1 & 422.20 \\
2 & 8.5 & 1 & 1 & 340.39 \\
3 & 6.5 & 5 & 1 & 481.76 \\
4 & 8.5 & 5 & 1 & 329.41 \\
5 & 6.5 & 1 & 5 & 383.52 \\
6 & 8.5 & 1 & 5 & 357.77 \\
7 & 6.5 & 5 & 5 & 430.87 \\
8 & 8.5 & 5 & 5 & 391.49 \\
9 & 6.5 & 3 & 3 & 377.27 \\
10 & 8.5 & 3 & 3 & 340.95 \\
11 & 7.5 & 1 & 3 & 403.67 \\
12 & 7.5 & 5 & 3 & 370.71 \\
13 & 7.5 & 3 & 1 & 347.92 \\
14 & 7.5 & 3 & 5 & 326.85 \\
15 & 7.5 & 3 & 3 & 333.64 \\
16 & 7.5 & 3 & 3 & 345.14 \\
17 & 7.5 & 3 & 3 & 332.13 \\
18 & 7.5 & 3 & 3 & 340.58 \\
19 & 7.5 & 3 & 3 & \\
20 & 7.5 & 3 & 3 & \\
\hline
\end{tabular}

For enzyme specific activity (U/mg), Fig. 1a and Fig. 1b graphically indicate the $\mathrm{AB}$, and $\mathrm{AC}$ interactions, respectively. According to Fig. 1a; increasing the $\mathrm{pH}$ during the low incubation period slightly reduced the specific activity, while the $\mathrm{pH}$ increases during the high incubation period resulted in much more reduction in the specific activity. As shown in Fig. 1b, increasing the $\mathrm{pH}$ at a low inoculum amount significantly reduced specific activity, while increasing the $\mathrm{pH}$ at high inoculum amounts led to a slight decrease in specific activity.
As may be indicated from the ANOVA table (Table 3) and graphs (Fig. 1a-1b), the most effective parameter for specific activity is the $\mathrm{pH}$, which is in interaction with both the incubation time and the inoculum amount. After all the data are investigated, the amount of inoculum was an insignificant effect on investigated levels in this work for all three response variables.

$\underline{\text { Table } 3 \text { ANOVA for enzyme specific activity }}$

\begin{tabular}{|c|c|c|}
\hline & \multicolumn{2}{|c|}{ Specific activity } \\
\hline Source & $\mathrm{p}$ value & Model coefficients for coded values \\
\hline Model & $<0.0001$ & +345.58 \\
\hline $\mathbf{A}(\mathbf{p H})$ & $<0.0001$ & -33.56 \\
\hline B (incubation time-day) & 0.0036 & +18.30 \\
\hline C (inoculum amount-\%) & 0.5298 & -3.29 \\
\hline $\mathbf{A B}$ & 0.0889 & -10.52 \\
\hline AC & 0.0029 & +21.13 \\
\hline $\mathbf{B}^{2}$ & 0.0039 & +32.06 \\
\hline $\mathbf{C}^{2}$ & 0.1356 & +14.38 \\
\hline Lack of fit & & 0.4329 \\
\hline $\mathbf{R}^{2}$ & & 0.9006 \\
\hline Adj. $\mathbf{R}^{2}$ & & 0.8427 \\
\hline Pred. $\mathbf{R}^{2}$ & & 0.6774 \\
\hline
\end{tabular}
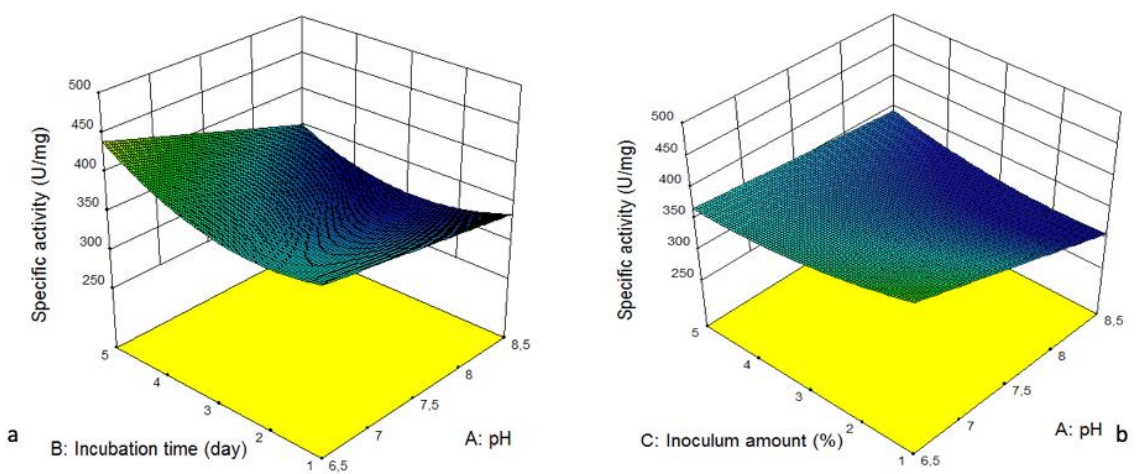

Figure 1 The response surface of double interaction of $\mathrm{pH}$, incubation time and inoculum amount: (a and b) for protease specific activity 


\section{Prediction and optimization}

The optimum value of response variables such as protease specific activity was predicted from the regression models by using numerical optimization algorithm. In the optimization, experimental and predicted maximum specific activity values are shown in Table 4. Predicted parameter levels are also indicated in Table 4 for protease activity. Confidence interval for response variable is also given at $95 \%$ in this table. Moreover, the test result of verification experiment performed at predicted parameter levels is represented in this table. As it can be indicated from this table, verification test result was found to be very close to predicted ones and fell between confidence intervals at $95 \%$.

Table 4 Predicted and verification test result for specific activity value.

\begin{tabular}{|c|c|c|c|c|c|c|}
\hline \multicolumn{7}{|c|}{ Response variable: Specific activity } \\
\hline \multicolumn{3}{|c|}{ Conditions } & \multicolumn{3}{|c|}{ Predicted value } & \multirow{2}{*}{$\begin{array}{l}\text { Verification test } \\
\text { Experimental result }\end{array}$} \\
\hline $\mathrm{A}(\mathrm{pH})$ & $\begin{array}{l}\text { B (incubation } \\
\text { time-day) }\end{array}$ & $\begin{array}{l}\text { D (inoculum } \\
\text { amount-\%) }\end{array}$ & $\begin{array}{c}\% 95 \\
\text { CI low }\end{array}$ & $\begin{array}{l}\text { Predicted } \\
\text { value }\end{array}$ & $\begin{array}{c}\% 95 \\
\text { CI max }\end{array}$ & \\
\hline 6.5 & 5.0 & 1.0 & 450.304 & 478.817 & 507.33 & 480.543 \\
\hline
\end{tabular}

\section{Characterization of crude protease}

\section{Determination of optimum temperature and $\mathrm{pH}$}

The temperature profile of protease activity is presented on Fig. 2. The maximum enzyme activity was obtained at $60{ }^{\circ} \mathrm{C}$. Similar reports were obtained in the literature. Jaouadi and coworkers reported that the optimum temperature of proteolytic enzyme from Bacillus pumilus CBS was $65^{\circ} \mathrm{C}$ (Jaouadi et al., 2008) The optimum temperature of proteolytic enzyme from Bacillus sp. was found as $40{ }^{\circ} \mathrm{C}$ by Josephine and his friends (Josephine et al., 2017). Harer and coworkers described the optimum temperature of protease from Bacillus thuringiensis-SH-II-1 A to be $45^{\circ} \mathrm{C}$ (Harer et al., 2018). Lakshmi and colleagues defined the optimum temperature of protease from Bacillus cereus strain S8 as 70 ${ }^{\circ} \mathrm{C}$ (Lakshmi et al., 2018).

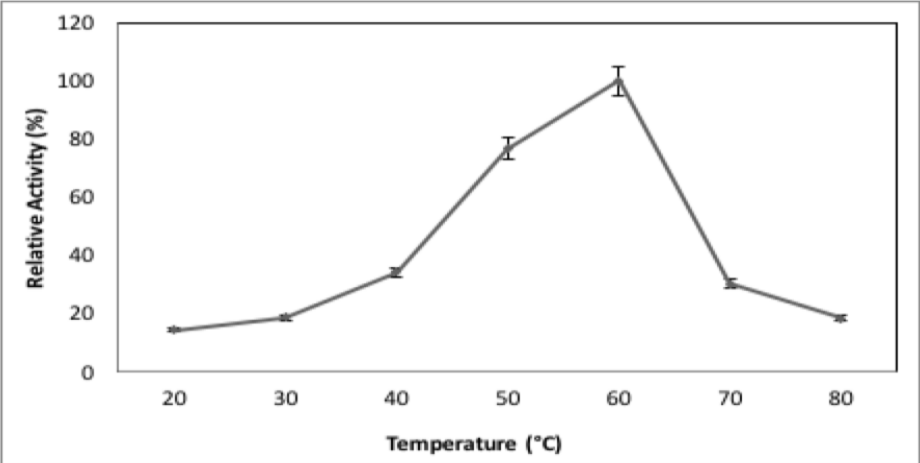

Figure 2 Optimal reaction temperature of the protease

The optimum $\mathrm{pH}$ of proteolytic activity was found to be 10.5 (Fig. 3). Similar results were described for several Bacillus strains in the literature. Harer et al. (2015) reported optimum $\mathrm{pH}$ for protease of Bacillus thuringiensis-SH-II-1A to be $\mathrm{pH}$ 10-11. Hadjidj et al. (2018) reported optimum $\mathrm{pH}$ of protease from Bacillus licheniformis K7A being as $\mathrm{pH}$ 10. In the same way, Lakshmi et al (2018) observed optimum activity of protease from Bacillus cereus strain S8 when $\mathrm{pH}$ was 10 .

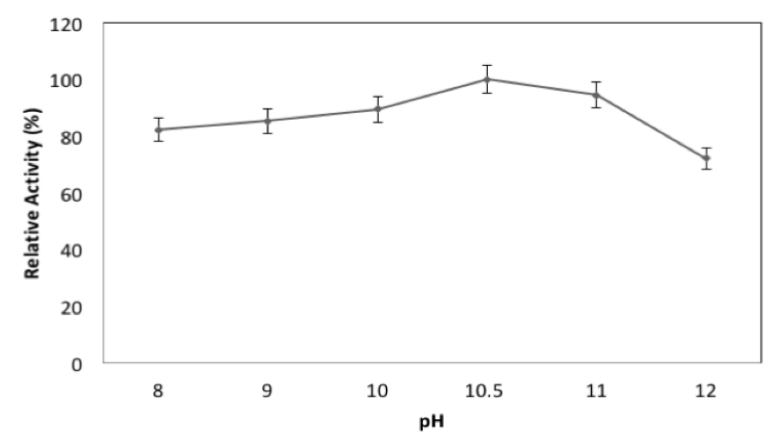

Figure 3 Optimal reaction $\mathrm{pH}$ of the protease

\section{Determination of thermostability and pH stability}

Protease activity obtained at $50{ }^{\circ} \mathrm{C}$ was accepted as $100 \%$. Relative activity was calculated based on this phrase. Bacillus sp. DB14 protease lost around $67 \%$ of activity at $60{ }^{\circ} \mathrm{C}$ (Fig. 4) after1 $\mathrm{h}$ incubation. Although the optimum temperature was $60{ }^{\circ} \mathrm{C}$, Bacillus sp. DB14 protease exhibited interestingly stability in the temperature range of $20^{\circ} \mathrm{C}$ and $50{ }^{\circ} \mathrm{C}$. Similarly, Lakshmi et al. (2018) reported thermostability of protease from Bacillus cereus strain S8 exhibiting in the temperature range of $30-80{ }^{\circ} \mathrm{C}$, while Hakim et al. (2018) showed that Bacillus subtilis AKAL7 protease was stable from $30{ }^{\circ} \mathrm{C}$ to $50{ }^{\circ} \mathrm{C}$. Jaouadi et al. (2008) determined that the protease of Bacillus pumilus CBS was stable in the temperature range $30-55^{\circ} \mathrm{C}$

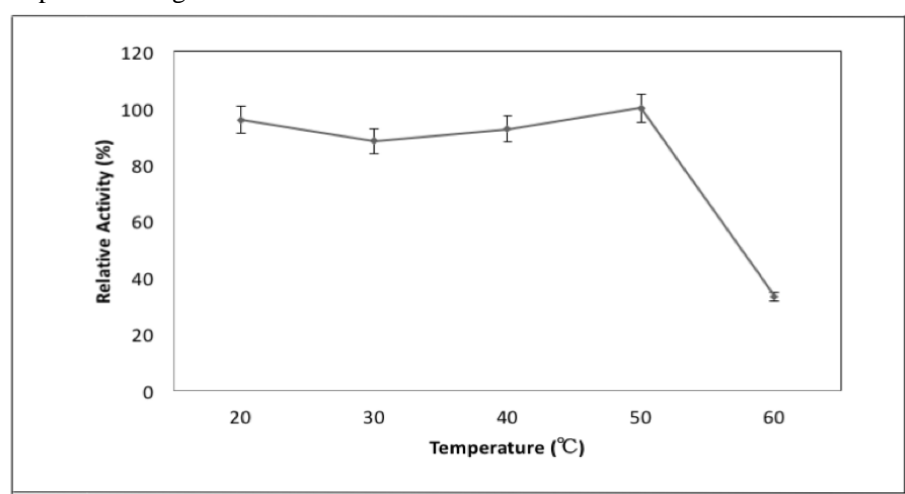

Figure 4 Effect of incubation temperature on protease stability

Protease activity obtained at $\mathrm{pH} 10.5$ was accepted as $100 \%$ and relative activity was calculated based on this phrase. Protease activities obtained at the range of pH 7-11 were stable (Fig. 5). Bacillus sp. DB14 protease lost around 69\% of activity at $\mathrm{pH} 12.5$, after $1 \mathrm{~h}$ incubation. Similar results were reported in the literature. The protease from Bacillus pumilus CBS showed stability from $\mathrm{pH} 7.0$ to $\mathrm{pH} 10.6$ (Jaouadi et al., 2008).

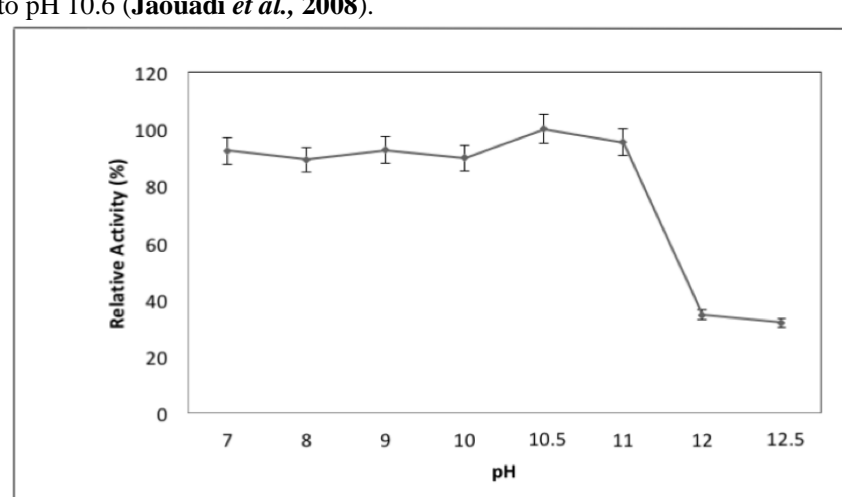

Figure 5 Effect of incubation $\mathrm{pH}$ on protease stability

Impact of different metals, metalloid and denaturants on protease activity

Inhibition of enzymatic activity was detected for $10 \mathrm{mM} \mathrm{Ni}^{2+}(80.44 \%$ of relative activity), $\mathrm{Fe}^{3+}\left(69.91 \%\right.$ of relative activity), $\mathrm{Hg}^{2+}$ (34.34\% of relative activity) $\mathrm{Cd}^{2+}\left(60.79 \%\right.$ of relative activity) and $\mathrm{B}^{3+}(65.65 \%$ of relative activity) (Fig. 6) $\mathrm{Cu}^{2+}$ ion enhanced protease stability, in 1.25 times, during 20 minutes at $30^{\circ} \mathrm{C}$. $\mathrm{Cu}^{2+}$ ions may be important for catalysis. It is reported that the activity of alkaline protease from Bacillus sp., Bacillus subtilis, and Bacillus megaterium RRM2 was decreased by $\mathrm{Fe}^{3+}, \mathrm{Hg}^{2+}, \mathrm{Zn}^{2+}$ and $\mathrm{Co}^{2+}$ (Venugopal and Saramma, 2007; Olajuyigbe and Falade, 2014; Hakim et al., 2018). 


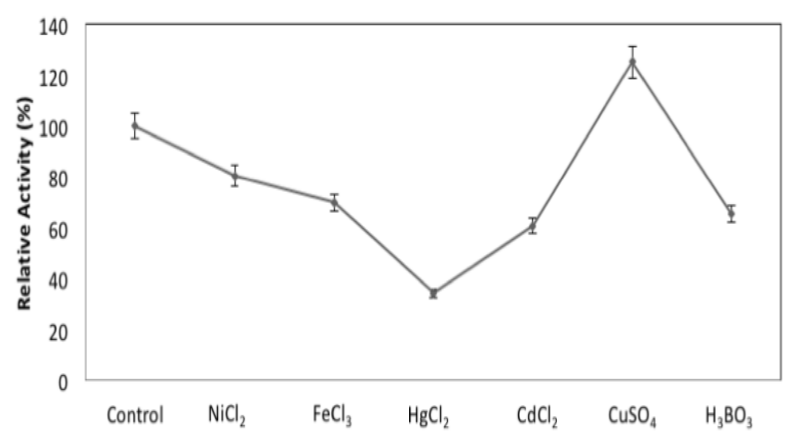

Figure 6 Effect of some metals and metalloids on enzyme stability Approximately $25 \%$ loss was detected in enzyme activity after adding $0,5 \mathrm{mM}$ and $1 \mathrm{mM}$ SDS (Fig. 7) to reaction medium. Other concentrations of denaturants did not cause a significant reduction in enzyme activity.

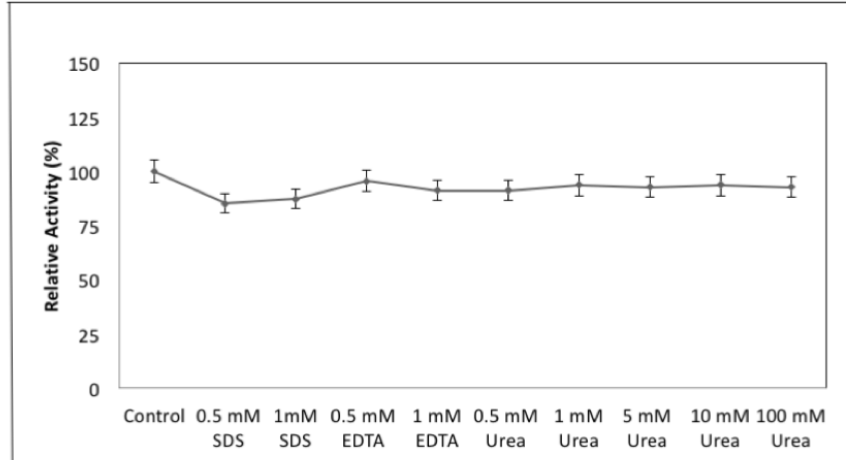

Figure 7 Effect of some denaturants on enzyme stability

In our study, boron ion inhibited protease activity. Boron toxicity may lead to inhibit protease activity. Uluisik et al. recommended a possible association between boron toxicity and translational control in yeast according to the observation that mutants showing boron resistance were all lacking genes that play a role in uridine base modifications at the wobble position of tRNAs throughout translation (Uluisik et al., 2011a). The same team hypothesized that boron exerted its toxic effect by activation of the overall amino acid control system and then inhibition of protein synthesis. Because the general amino acid control pathway is conserved among eukaryotes, the mechanism of boron toxicity may be of common significance (Uluisik et al., 2011b).

\section{CONCLUSION}

23 bacterial strains were isolated from Kirka boron mine distinct and these isolates were screened in terms of proteolytic activity. Among these isolates, Bacillus sp. DB14 had the highest activity. For optimization of enzyme production, Central Composite Design was utilized. Bacillus sp. DB14 protease exhibited interestingly stability in the temperature range of $20{ }^{\circ} \mathrm{C}$ and $50{ }^{\circ} \mathrm{C}$. Protease activity values obtained at the range of $\mathrm{pH} 7-11$ were stable. Furthermore, this enzyme indicated tolerance to different denaturants including urea, EDTA, SDS. These results revealed that the alkaline protease from Bacillus DB14 might be potential for biotechnological applications. Therefore this enzyme with stability in the wide range of temperature and $\mathrm{pH}$ may find wide usage areas in different industries such as detergent and leather.

Conflict of interest : The authors declare that they have no conflict of interest.

Acknowledgements: Belma NURAL YAMAN is supported by TUBITAKBIDEB 2228-B National Scholarship Programme for PhD Students.

\section{REFERENCES}

Ahmed, I., Yokota, A., \& Fujiwara, T. (2006). A novel highly boron tolerant bacterium, Bacillus boroniphilus sp. nov., isolated from soil, that requires boron for its growth. Extremophiles, 11(2), 217-224. http://dx.doi.org/10.1007/s00792006-0027-0

Ahmed, I., \& Fujiwara, T. (2010). Mechanism of boron tolerance in soil bacteria. Canadian Journal of Microbiology, 56(1), 22-26. http://.doi.org/10.1139/w09$\underline{106}$
Akkır, E. Y., Şahin, Y. B., Gedikli, S., Çelik, P. A., \& Çabuk, A. (2017). Extremely Thermostable, EDTA-Resistant Alkaline Protease From A Thermophilic Geobacillus subterraneus C2-1 Isolate. Journal of Microbiology, $\begin{array}{llll}\text { Biotechnology and Food } \quad \text { Sciences, } & 7(1), & 50-56\end{array}$ http://dx.doi.org/10.15414/jmbfs.2017.7.1.50-5

Aytar, P., Kay, C. M., Mutlu, M. B., \& Çabuk, A. (2013). Coal Desulfurization with Acidithiobacillus ferrivorans, from Balya Acidic Mine Drainage. Energy \& Fuels, 27(6), 3090-3098. http://dx.doi.org/10.1021/ef400360t

Aytar, P., Kay, C. M., Mutlu, M. B., Çabuk, A., \& Johnson, D. B. (2014) Diversity of acidophilic prokaryotes at two acid mine drainage sites in Turkey. Environmental Science and Pollution Research, 22(8), 5995-6003. http://dx.doi.org/10.1007/s11356-014-3789-4

Banerjee, U. C., Sani, R. K., Azmi, \& W., Soni, R. (1999). Thermostable alkaline protease from Bacillus brevis and its characterization as a laundry detergent additive. Process Biochemistry, 35(1-2), 213-219. http://dx.doi.org/10.1016/s0032-9592(99)00053-9

Bolaños, L., Lukaszewski, K., Bonilla, I., \& Blevins, D. (2004). Why boron? Plant Physiology and Biochemistry, 42(11), 907-912. http://dx.doi.org/10.1016/j.plaphy.2004.11.002

Bradford, M. (1976). A Rapid and Sensitive Method for the Quantitation of Microgram Quantities of Protein Utilizing the Principle of Protein-Dye Binding Analytical Biochemistry 72(1-2) 248-254. http://dx.doi.org/10.1006/abio.1976.9999

Chen, X., Schauder, S., Potier, N., Van Dorsselaer, A., Pelczer, I., Bassler, B. L., \& Hughson, F. M. (2002). Structural identification of a bacterial quorum-sensing signal containing boron. Nature, 415(6871), 545-549. http://dx.doi.org/10.1038/415545a

Goldbach, H. E., \& Wimmer, M. A. (2007). Boron in plants and animals: Is there a role beyond cell-wall structure? Journal of Plant Nutrition and Soil Science, 170(1), 39-48. http://dx.doi.org/10.1002/jpln.200625161

González-Fontes, A., Rexach, J., Navarro-Gochicoa, M. T., Herrera-Rodríguez, M. B., Beato, V. M., Maldonado, J. M., \& Camacho-Cristóbal, J. J. (2008). Is Boron involved solely in structural roles in vascular plants? Plant Signaling \& Behavior, 3(1), 24-26. http://dx.doi.org/10.4161/psb.3.1.4812

Hadjidj, R., Badis, A., Mechri, S., Eddouaouda, K., Khelouia, L., Annane, R., ... \& Jaouadi, B. (2018). Purification, biochemical, and molecular characterization of novel protease from Bacillus licheniformis strain K7A. International Journal of Biological Macromolecules, 114, 1033-1048. http://dx.doi.org/10.1016/j.ijbiomac.2018.03.167

Sunil, L. H., Manish, S. B., \& Neela, M. B. (2018). Isolation, purification and partial characterization of thermostable serine alkaline protease from a newly isolated Bacillus thuringinsis-SH-II-1A. African Journal of Biotechnology, 17(7), 178-188. http://dx.doi.org/10.5897/ajb2015.14831

Hasan, F., Shah, A. A., \& Hameed, A. (2006). Industrial applications of microbial lipases. Enzyme and Microbial Technology, 39(2), 235-251. http://dx.doi.org/10.1016/j.enzmictec.2005.10.016

Hunt, C. D. (2012). Dietary boron: Progress in establishing essential roles in human physiology. Journal of Trace Elements in Medicine and Biology, 26(2-3), 157-160. http://dx.doi.org/10.1016/j.jtemb.2012.03.014

Irschik, H., Schummer, D., Gerth, K., Höfle, G., \& Reichenbach, H. (1995). Antibiotics from gliding bacteria. No.60. The Tartrolons, New Boron-containing Antibiotics from a Myxobacterium, Sorangium cellulosum. The Journal of Antibiotics, 48(1), 26-30. http://dx.doi.org10.7164/antibiotics.48.26

Jaouadi, B., Ellouz-Chaabouni, S., Rhimi, M., \& Bejar, S. (2008). Biochemical and molecular characterization of a detergent-stable serine alkaline protease from Bacillus pumilus CBS with high catalytic efficiency. Biochimie, 90(9), 12911305. http://dx.doi.org/10.1016/j.biochi.2008.03.004

Josephine, F. S., Ramya, V. S., Devi, N., Ganapa, S. B., \& Vishwanatha, T. (2017). Isolation, production and characterization of protease from Bacillus sp isolated from soil sample. Journal of Microbiology and Biotechnology Research, 2(1), 163-168.

Hakim, A., Bhuiyan, F. R., Iqbal, A., Emon, T. H., Ahmed, J., \& Azad, A. K. (2018). Production and partial characterization of dehairing alkaline protease from Bacillus subtilis AKAL7 and Exiguobacterium indicum AKAL11 by using organic municipal solid wastes. Heliyon, 4(6), e00646. http://dx.doi.org/10.1016/j.heliyon.2018.e00646

Kobayashi, M., Matoh, T., \& Azuma, J. (1996). Two Chains of Rhamnogalacturonan II Are Cross-Linked by Borate-Diol Ester Bonds in Higher Plant Cell Walls. Plant Physiology, 110(3), 1017-1020. http://dx.doi.org/10.1104/pp.110.3.1017

Kohno, J., Kawahata, T., Otake, T., Morimoto, M., Mori, H., Ueba, N., Nishio, M., Kinumaki, A., Komatsubara, S., \& Kawashima, K. (1996). Boromycin, an Anti-HIV Antibiotic. Bioscience, Biotechnology, and Biochemistry, 60(6), 10361037. http://dx.doi.org/10.1271/bbb.60.1036

Korkmaz, F., Deniz Sönmez, G., Aytar Çelik, P., Mutlu, M. B., \& Çabuk, A. (2017). Toxicity and mutagenicity assessment of a boron mine drainage water. Water and Environment Journal, 32(2), 250-258. http://dx.doi.org/10.1111/wej.12321 
Lakshmi, B. K., Muni Kumar, D., \& Hemalatha, K. P. (2018). Purification and characterization of alkaline protease with novel properties from Bacillus cereus strain S8. Journal of Genetic Engineering and Biotechnology, 16(2), 295-304. http://dx.doi.org/10.1016/j.jgeb.2018.05.009

Mateo, P., Bonilla, I., Fernández-Valiente, E., \& Sanchez-Maeso, E. (1986) Essentiality of Boron for Dinitrogen Fixation in Anabaena sp. PCC 7119. Plant Physiology, 81(2), 430-433. http://dx.doi.org/10.1104/pp.81.2.430

Nural Yaman, B., Deniz Sonmez, G., Aytar Celik, P., Korkmaz, F., Mutlu, M. B. \& Cabuk, A. (2019). Culture-dependent diversity of boron-tolerant bacteria from boron mine tailings pond and solid wastes. Water and Environment Journal, 33(4), 574-581. http://dx.doi.org/10.1111/wej.12429

Olajuyigbe, F. M. \&, Falade, A. M. (2014). Purification and partial characterization of serine alkaline metalloprotease from Bacillus brevis MWB01. Bioresources and Bioprocessing, 1(1). http://dx.doi.org/10.1186/s40643-0140008-6

Özçelik, B., Aytar, P., Gedikli, S., Yardımcı, E., Çalışkan, F., Çabuk, \& A. (2013). Production of an alkaline protease using Bacillus pumilus D3 without inactivation by SDS, its characterization and purification. Journal of Enzyme Inhibition and Medicinal Chemistry, 29(3), 388-396. http://dx.doi.org/10.3109/14756366.2013.788503

Rowe, R. I., Eckhert, C. D. (1999). Boron is required for zebrafish embryogenesis. Journal of Experimental Biology, 202(12), 1649-1654.

Satyanarayana, T., Raghukumar, C., \& Shivaji, S. (2005). Extremophilic microbes: Diversity and perspectives. Current Science, 89(1), 78-90.

Scorei, R. (2012). Is Boron a Prebiotic Element? A Mini-review of the Essentiality of Boron for the Appearance of Life on Earth. Origins of Life and Evolution of Biospheres, 42(1), 3-17. http://dx.doi.org/10.1007/s11084-0129269-2

Takami, H., Akiba, T., \& Horikoshi, K. (1989). Production of extremely thermostable alkaline protease from Bacillus sp. no. AH-101. Applied Microbiology and Biotechnology, 30(2). http://dx.doi.org/10.1007/bf00263997

Uluisik, I., Kaya, A., Unlu, E. S., Avsar, K., Karakaya, H. C., Yalcin, T., \& Koc, A. (2011). Genome-wide identification of genes that play a role in boron stress response in yeast. Genomics, 97(2), 106-111. http://dx.doi.org/10.1016/j.ygeno.2010.10.006

Uluisik, I., Kaya, A., Fomenko, D. E., Karakaya, H. C., Carlson, B. A., Gladyshev, V. N., \& Koc, A. (2011b). Boron Stress Activates the General Amino Acid Control Mechanism and Inhibits Protein Synthesis. PLoS ONE, 6(11), e27772. http://dx.doi.org/10.1371/journal.pone.0027772

Venugopal, M., \& Saramma, A. V. (2007). An alkaline protease from Bacillus circulans BM15, newly isolated from a mangrove station: characterization and application in laundry detergent formulations. Indian Journal of Microbiology, 47(4), 298-303. http://dx.doi.org/10.1007/s12088-007-0055-1

Berneman, A. (2002). Proteins: Biochemistry and Biotechnology. Edited by Gary Walsh, published by John Wiley \& Sons, 2001, 547 p., Biochimie, 84(4), 353. http://dx.doi.org/10.1016/s0300-9084(02)01394-9

Warington, K. (1923). The Effect of Boric Acid and Borax on the Broad Bean and certain other Plants, Annals of Botany, 37(4), 629-672. http://dx.doi.org/10.1093/oxfordjournals.aob.a089871 